\title{
Using the Learning Activities Survey to Examine Transformative Learning Experiences in Two Graduate Teacher Preparation Courses
}

\author{
Vicki Caruana, PhD \\ Assistant Professor of Education \\ Mount Saint Mary College \\ Kelli Woodrow, PhD \\ Associate Professor, School of Education \\ Regis University \\ Luis Pérez, PhD \\ Adjunct Faculty, School of Education \\ Regis University
}

\begin{abstract}
The Learning Activities Survey (LAS) detected whether, and to what extent, a perspective transformation occurred during two graduate courses in teacher preparation. The LAS examined the types of learning identified as contributing to their transformative experiences. This study examined pre-service teachers' critical reflection of the course materials and learning experiences in a Capstone course in Reflective Teaching and a course in Universal Design for Learning (UDL). Results suggest that similar learning experiences were identified as triggering a perspective transformation. When learners have the opportunity to engage in critical reflection, they may more easily question their personal perspectives as a result.
\end{abstract}

\section{Background \& Rationale}

Developing and raising pre-service teachers' critical consciousness or conscientização (Freire, 1970, 1997) is an essential step to preparing them to work as change agents with an increasingly diverse student population. National teacher preparation standards include language around advocacy for diverse learners and families (Council of Chief State School Officers, 2011). The expectation is that teachers will act on the learner variability they find in their classrooms to promote quality instruction and student engagement.

However, pre-service teachers often resist critical education practices that challenge their notions of self (identity), society and their interaction (e.g., Böhmer, \& Briggs, 1991; Chan \& Treacy, 1996; Gay \& Kirkland, 2003; Johnson, 2006; Ukpokodu, 2003). These acts of resistance often prevent reflection on social conditions that would lead to action and hamper teacher educators' ability to train teachers as change agents.

Learner variability in the $\mathrm{K}-12$ school environment is one of the greatest challenges to new teachers (Barge, 2012). New teachers' ability to think beyond traditional efficiency models of instruction on behalf of the myriad of learners in their classrooms is paramount to their success. Learner variability has increased and research has determined that it is context-dependent (Roberts, Park, Brown, \& Cook, 2011); therefore, university faculty should also expect that like $\mathrm{K}-12$ students, their college students will display learner variability. Universal Design for Learning (UDL) is one approach to comprehensively address learner variability in any classroom. "UDL applied to teaching and learning provides a lens that focuses targeted approaches on supporting student's affective, strategic and recognition learning networks" (Smith, 2012, p. 31). In other words, to apply UDL to the university classroom, faculty need to scaffold instruction in a way that promotes student learning, addresses prior learning and preconceived ideas, develops a deep understanding of context and facts, and develops a metacognitive approach to learning. Pre-service teachers preparing to work with a diverse classroom need learning experiences that are transformative in nature and design. 
This article seeks to explore the use of a survey instrument in identifying whether or not transformative learning has occurred in pre-service teachers and if so, what teaching and learning activities have been identified as contributing to preservice teacher's transformation? Transformative learning offers a compelling lens through which the development of teachers responding to student variability as change agents can be viewed, and offers the faculty member a way to study one's teaching in order to refine and improve student learning experiences ("SoTL: What Is", 2014). With a focus on the scholarship of teaching and learning (SoTL), this inquiry into student learning advances the practice of teaching by teacher educators by quantifying and qualifying student responses or reactions to their learning experiences (Bender \& Gray, 1999).

\section{Universal Design for Learning}

Originally developed at the Center for Applied Special Technology (CAST) in the 1980s, the UDL is a framework for curriculum design that emphasizes flexibility in order to account for the variability and diversity of learners. UDL is mentioned in the Higher Education Opportunity Act of 2008 (HEOA) as a scientifically valid framework for guiding educational practice that: (a) provides flexibility in the ways information is presented, in the ways students respond or demonstrate knowledge and skills, and in the ways students are engaged; and (b) reduces barriers in instruction, provides appropriate accommodations, supports, and challenges, and maintains high achievement expectations for all students, including students with disabilities and students who are limited English proficient (National Center on UDL, 2013). UDL draws upon the latest insights from neuroscience and education research, and leverages the flexibility of digital technology to design learning environments that from the outset offer options for diverse learner needs (Meyer, Rose, \& Gordon, 2014).

The UDL guidelines were instrumental in the design of the UDL course examined in this inquiry. Students enrolled in the UDL course were explicitly prompted each week to relate their classroom learning to problems and situations encountered in their practice teaching and service learning placements. By design, the course modeled many of the practices and behaviors that educators need to possess in order to successfully implement UDL in their own classrooms. Such

...university faculty should modeling has been highlighted by CAST as an also expect that like $\mathbf{K - 1 2}$ essential element of the transformation into an students, their college effective learning community of expert leaners at students will display the individual level and an expert learning system learner variability.

at the systems level (Meyer et al., 2014). The increasingly "varied student body presents diverse learning needs often not addressed through traditional instructional approaches in higher education" (Roberts et al., p. 5). The persistent questioning of the norms, habits, and techniques of teaching is inherent in both the Capstone in Reflective Teaching and the UDL courses. The learning experiences designed in these courses support the transformation and enactment of the pre-service teacher's personal purpose to make a difference (Fullan, 1993).

\section{Transformative Learning Theory (TLT)}

TLT suggests that there are stages that a person experiences that lead to a change in perspective and therefore a new way of acting. TLT offers a framework through which we can detect the nature and extent of a desired perspective transformation. This theory is a popular adult learning theory through which faculty in higher education can understand, design, and even foster experiences that seriously challenge students to assess their perspectives by which they are subsequently changed (Meziow, 1991; Quinnan, 1997). Because teacher educators design learning experiences for teacher candidates in a way that seeks to transform 
their knowledge, skills and perceptions to that of professional teachers and in some circumstances that of change agents, this theory offers a compelling lens through which this process can be viewed (Caruana, 2011).

Applying TLT to the development of teachers as social change agents appropriately acknowledges and examines the teachers' struggle to make a critical assessment of their own assumptions and incorporate this transformation into their professional practice (Hammerness et al., 2005). The transformative process ultimately displays enaction in the learner, not simply awareness. Enaction occurs when the pre-service teacher emulates the beliefs and behaviors portrayed in the learning experiences included in their teacher preparation (Jones, 2009). The transformation of one's perspectives is one way in which learning and the enactment of new actions can occur (Mezirow, Taylor, \& Associates, 2009). Central to fostering transformative learning however, is an examination of the factors or triggers that cause transformative learning.

Higher education must be a place where teacher candidates are prepared to "think and act dynamically" (Glisczinski, 2007, p. 319); they need to know how to act out their learning in their own lives. Without this ability, teacher candidates become mere teaching technicians following the prescription of a linear path that does not exist in a non-linear post-modern world. For this reason, we have chosen transformative learning theory to frame this study.

\section{Method}

\section{Participants \& Courses}

Three faculty members in the School of Education distributed the Learning Activities Survey in sections of two different graduate level accelerated courses: a UDL course and a Capstone in critical reflection. A total of 55 students from two courses participated in the LAS. However, data from six (6) special education preservice teachers was too small of a sample to draw any meaningful conclusions. Analyses were based on a reduced sample of 49 participants. All of the students were graduate students from a private Western college for professional studies within a liberal arts university. All of the students were seeking teaching certification through a master's program. There were a total of 34 students in the Elementary Education program, nine students in the Secondary Education program, six students in the Special Education program, and one student in the Early Childhood Special Education program. The age of the students ranged from $25-$ 29. Forty-two of the students were female and seven were male. The majority of the students were White, non-Hispanic $(n=42)$ except for seven who identified as either Black, non-Hispanic or Hispanic. These demographics were representative of students in this program at this university.

In an effort to cultivate teachers as change agents, a Capstone course in critically reflective teaching was developed in a graduate teacher education program at this institution. The course was delivered during accelerated eight week terms during the 2011-2012 academic year in both online and face-to-face formats. Part of the intent of this Capstone course, in which the LAS was used, was to provide experiential learning that was consciousness-raising in order that pre-service teachers would become aware of their own and others' beliefs and hopefully provide opportunities for them to question their personal perspectives. Forty-eight preservice teachers participated in the survey out of the five sections of the course.

The second course, Universal Design for Learning: a framework for teaching and learning, was also delivered during accelerated eight week terms during the 2013-2014 academic year in both online and face-to-face formats. The research questions for this study addressed the problem of whether including a dedicated course in UDL as part of a teacher preparation program impacts the participants' ability to address learner variability in their own practice as a result. Seven pre-service teachers participated in the survey out of the two sections of the course. 
Faculty in both courses sought to provide learning experiences that might trigger a transformation in the pre-service teachers' perspectives and then take action in their new understanding. Participants engaged in similar learning activities in both courses.

\section{Procedures \& Measures}

This mixed method study employed survey research which included a keyword analysis of the two open ended questions included in the survey. The Learning Activities Survey (LAS) was developed by Kathleen King (2009) to indicate the presence and possible triggers of transformative learning and was adapted to contain the kinds of activities included in the course. The LAS was administered at the end of an eight week term to 48 graduate teacher licensure students who were enrolled in one of five sections of the Capstone course during the 2010-2011 academic year. The LAS was then administered at the end of an eight week term to seven graduate teacher licensure students enrolled in one of two sections of a course in UDL during the 2013-2014 academic year.

The Learning Activities Survey (LAS). We chose to employ the LAS as a way to obtain data about the transformative learning experiences in the sample as well as to identify meaningful learning experiences by participants. The LAS was developed to detect, identify, and categorize transformative experiences (King, 1997) in the higher education context. The expressed purpose of the LAS is to identify "whether adult learners have had a perspective transformation in relation to their educational experience; and if so, determining what learning activities have contributed to it" (King, 2009, p. 14). The instrument has four major parts: Part 1 identifies the stages of perspective transformation; Part 2 determines which learning experiences may have contributed to the perspective transformation (PT); Part 3 consists of a series of questions designed to determine in which of the learning activities participants have engaged; and Part 4 collects information on demographic characteristics of the respondents that are suggested from the literature on transformative learning theory.

The original LAS was adapted for use with pre-service teachers according to the guidelines provided by the survey's developer (King, 2009) which included modifying the PT (Perspective Transformation) Index definitions to match the unique context of this study. We also changed the learning activities (Items 4 and 7) and demographic questions (Items 10-14) to be more appropriate for pre-service teachers. Items 1, 2, 3, and 5 are those used to establish the PT-Index and were not changed so as not to affect the validity of the instrument.

Reliability of the LAS was addressed by the developer (King, 2009) in a unique manner due to the fact that the instrument is administered at different points in time and might elicit responses about different perspective transformation experiences. For this reason a "hermeneutical perspective" (Gall, Gall, \& Borg, 2003 , p. 505) using several evaluations to arrive at a final evaluation was employed to establish reliability. A hermeneutic perspective considers differences as parts to be interpreted "until they can be reconciled into a satisfactory overall interpretation that provides an understanding of the differences" (p. 217). Through this process, the reliability of the LAS was strengthened.

The LAS that was modified for both the Capstone course and the UDL course included 25 questions: 18 multiple choice questions, two open ended questions, and five demographic questions. The survey was deployed using SurveyMonkey through a link given to participants at the end of their course. A copy of the survey used in both the Capstone and UDL courses are included in Appendix A. An overall PT-Index is obtained from this instrument. The PT-Index is a single score derived from Items 1, 2, 3, and 5 of this instrument and indicates whether participants experienced a perspective transformation in his or her educational experience. PT1 indicates that the participant does not believe they 
have had a transformative experience within this context. PT2 indicates that the participant believes they've had a transformative experience due to something outside of those learning experiences designed by teacher educators (e.g., experiences within or connected to their student teaching experience). PT3 indicates that the participant believes they've had a transformative experience due to the learning experiences designed by teacher educators in their course.

\section{Results}

To address the first research question, whether and to what extent the learning activities designed within two teacher preparation courses impacted the pre-service teachers' abilities to address learner variability in their own practice, a calculation of percentage was conducted on the LAS across both courses. In the Capstone course, results indicated more than one third of those who experienced transformative learning reported that both verbally discussing their $\ldots \mathbf{7 1 \%} \quad(\boldsymbol{n}=\mathbf{3 5})$ indicated assumptions/beliefs/values $(40 \%)$ and personal experiencing transformative reflection (40\%) contributed to the perspective learning while enrolled in transformation. If we rank these activities by learning while enrolled in their contribution, the following were indicated
the courses.

most frequently by those who experienced transformative learning: (1) $40 \%$ indicated verbally discussing their assumptions/beliefs/values, (2) $40 \%$ indicated personal reflection, (3) $33 \%$ indicated writing about their assumptions/beliefs/values, and (4) $27 \%$ indicated class/group projects. Although 16 learning experiences were included in the LAS, these learning experiences in particular were stronger indicators of transformation than other activities and offered participants as opportunity to work through their transformative process during their Capstone course.

In the UDL course results indicated that more than three quarters of those who experienced transformative learning reported that the following learning experiences contributed to their transformative process: $(80 \%)$ readings in textbook, (80\%) discussion questions, (80\%) service learning experiences, $(80 \%)$ school field experience, and (80\%) personal reflection. There is an equal distribution across five of the six surveyed learning experiences in the UDL course. A copy of the personal reflection cited as contributing to the participants' transformative process is included in Appendix B.

To determine if the use of the LAS effectively detected transformative learning experiences of participants, items $1,2,3$, and 5 were those used to establish the PT-Index from participants in both the Capstone and the UDL courses. PT3 indicates that the participants believe they have had a transformative experience due to the learning experiences designed by teacher educators in their Capstone course. PT2 indicates that the participants believe they have had a transformative experience due to something outside of those learning experiences designed by teacher educators (e.g., experiences within or connected to their student teaching experience). For the purposes of this analysis, PT2 and PT3 were combined because both are indicators of a perspective transformation $(n=31)$.

Out of 49 pre-service teachers surveyed, $71 \% \quad(n=35)$ indicated experiencing transformative learning while enrolled in the courses. In addition, approximately $73 \%(n=25)$ of the Elementary pre-service teachers $(n=34)$ indicated transformative learning, while approximately $72 \%(n=8)$ of the Secondary preservice teacher candidates $(n=11)$ indicated experiencing transformative learning. Although six (6) special education pre-service teachers were surveyed, the $n$ was too small to draw any meaningful conclusions.

A second level of content analysis (keyword) was conducted to determine which types of interactions were referenced by participants in the two open ended questions of the LAS., all of which indicated having a transformative experience (PT2 or PT3). A sample of the keyword analysis results appear in Table 1. 
Table 1

Keyword Analysis to the Question 'Was it a Person Who Influenced this Change?'

\begin{tabular}{|c|c|c|}
\hline Participant ID Code & Examples & Keyword \\
\hline SP103W & "Through research of proven theories" & Research \\
\hline SP104W & $\begin{array}{l}\text { "The books and literature we read about } \\
\text { 'the invisible backpack,' the 'hidden } \\
\text { curriculum' and teaching the 'hidden rates } \\
\text { of the middle class' }\end{array}$ & Research \\
\hline SP106H & "Texts read in class" & Research \\
\hline SU103W & $\begin{array}{l}\text { "Research studies; in-class conversations; } \\
\text { gathering data and comparing best } \\
\text { practices with observed practices" }\end{array}$ & Research \\
\hline SP101W & $\begin{array}{l}\text { "Student and parents I met while student } \\
\text { teaching" }\end{array}$ & Student \\
\hline SP1010 & "In addition to the students themselves" & Student \\
\hline SU104K & "My students" & Student \\
\hline SP102H & $\begin{array}{l}\text { "My background gave me some insight } \\
\text { into my students' lives" }\end{array}$ & Student \\
\hline SP105K & $\begin{array}{l}\text { "Getting to know my own students helped } \\
\text { me to realize this, reflecting in class } \\
\text { helped me understand the importance" }\end{array}$ & Student \\
\hline SP107W & $\begin{array}{l}\text { "I participated in a home visit/special } \\
\text { education students that changed my } \\
\text { thinking on home life for students and } \\
\text { behavior in the classroom" }\end{array}$ & Student \\
\hline SP109W & "My students" & Student \\
\hline SU102W & "Working with parents of my students" & Student \\
\hline
\end{tabular}

Note. 'Keyword' denotes codes used in analysis.

Approximately $30 \%(n=11)$ of those who responded to the open ended question and experienced a perspective transformation indicated that interacting with their students influenced their change. Additionally, $10 \%(n=15)$ of those who responded to the open ended questions and who experienced a perspective transformation indicated that learning about learner variability influenced their change. Twenty-five percent $(n=9)$ of participants did not complete the open-ended question. 


\section{Discussion}

The purpose of this study was to expand the use of the LAS by administering it to graduate pre-service teachers in two courses that provided learning experiences meant to trigger a perspective transformations at the end of an eight week course and to identify which of the teacher educator designed learning experiences were considered a part of that perspective transformation by the pre-service teachers. By conducting the LAS at the end of the courses and analyzing the data well after the courses ended it offered the faculty a retrospective of the learning experiences so that they could then make strategic changes in future courses to

...suggesting that there is potential for teacher educators to design learning experiences that trigger transformation. provide meaningful experiences that may trigger a perspective transformation. By examining the learning experiences in two different courses that had similar outcomes, it provides for a more comprehensive evaluation of whether and to what extent teacher educators affect a desired shift in the perspectives in pre-service teachers at the graduate level. In both courses, personal reflection was cited as a learning experience that contributed to the participants' perspective transformations.

The results indicated that there was a perspective transformation toward addressing learner variability by pre-service teachers at the end of both of these courses; suggesting that there is potential for teacher educators to design learning experiences that trigger transformation. When learners have the opportunity to engage in learning experiences that center on critical reflection and rationale dialogue, they more easily question their personal perspectives and move toward taking action as a result.

\section{Future Research \& Limitations}

Further examination of the perspective transformations of adult learners with regard to their prior position in the transformative process is warranted. For example, those that did not indicate they had a perspective transformation may already embody the perspectives of change agents; therefore, they did not experience a shift in their perspectives. Repeating this study at another point in the teacher preparation process may also be of value. For example, the UDL course occurs during the first few courses in the program sequence and the Capstone course occurred at the end of the sequence; it might be prudent to determine if transformative learning is occurring at the midpoint of the program as well to see if there are continual opportunities to move toward the expected outcomes. Although these results represent the perspective transformations of these selected participants, the small sample size does not allow for generalizability to a larger population. Instead it does generalize to theory as there is evidence to support the application of transformative learning theory. In addition, it would be interesting to examine if the format of the course (online or face to face) made a difference.

\section{Conclusion}

This study sought to examine the use of the LAS to detect if and to what extent pre-service teachers enrolled in two graduate level courses had a perspective transformation, and to better understand what, if any, teacher educator-developed learning experiences may have contributed to that perspective transformation. The findings indicated that learning experiences that were rich in critical reflection and offered opportunities for rational dialogue both triggered perspective transformation and were identified as meaningful by participants. This research shows that when participants experience a perspective transformation, they are engaged in transformative learning that then may lead to enaction. However, no causal links have been determined through this inquiry. Teacher educators can provide 
transformative experiences and improve their own practice by developing those experiences that trigger transformation and therefore meet their expressed program or student learning outcomes.

\section{References}

Barge, J. D. (2012). Fact Sheet 4: Standard 2: Instructional planning. Retrieved from Georgia Department of Education, Teacher Keys Effectiveness System Fact Sheets website: http://www.gadoe.org/SchoolImprovement/Teacher-and-LeaderEffectiveness/Documents/TKES\%20Fact \%20\%20Sheets\%207-11-2012.pdf

Bender, E., \& Gray, D. (1999, April). The scholarship of teaching. Research and Creative Activity, 22(1). Retrieved from Indiana University, Office of Research and the University Graduate School website: http://www.indiana.edu/ rcapub/v22n1/p03.html

Böhmer, S., \& Briggs, J. L. (1991). Teaching privileged students about gender, race, and class oppression. Teaching Sociology, 19, 154-163. doi: $10.2307 / 1317846$

Caruana, V. (2011). Preservice teachers' perceptions of their perspective transformations: A case study (Doctoral dissertation). Retrieved from University of South Florida, Graduate Theses and Dissertations website: http://scholarcommons.usf.edu/etd/303

Chan, C. S., \& Treacy, M. J. (1996). Resistance in multicultural courses. American Behavioral Scientist, 40(2), 212-222.

$10.1177 / 0002764296040002012$

Council of Chief State School Officers. (2011, April). Interstate teacher assessment and support consortium (InTASC) model core teaching standards: A resource for state dialogue (April 2011). Washington, DC: Author. Retrieved from http://www.ccsso.org/Resources/Publica tions/InTASC_Model_Core_Teaching_Sta ndards_A_Resource_for_State_Dialogue _(April_2011).html
Freire, P. (1970). Pedagogy of the oppressed. New York, NY: Herder and Herder.

Freire, P. (1997). Education for critical consciousness. New York, NY: The Continuum.

Fullan, M. (1993). Why teachers must become change agents. The Professional Teacher, 50(6), 12-17. Retrieved from http://www.ascd.org/publications/educa tional-leadership/

mar93/vol50/num06/Why-Teachers-

Must-Become-Change-Agents.aspx

Gall, M. D., Gall, J. P., \& Borg, W. R. (2007). Educational research ( $8^{\text {th }}$ ed.). Boston, MA: Allyn \& Bacon.

Gay, G., \& Kirkland, K. (2003). Developing cultural critical consciousness and self-reflection in preservice teacher education. Theory into Practice, 42(3), 181-187. Retrieved from

http://www.wou.edu/ tmcwilliams08/D eveloping $\% 20$ Cultural\%20Critical\%20Co nsciousness_files/ContentServer.pdf

Glisczinski, D. J. (2007). Transformative higher education: A meaningful degree of understanding. Journal of Transformative Education, 5, 317._doi: $10.1177 / 1541344607312838$

Hammerness, K., Darling-Hammond, L., Bransford, J., Berliner, D., CochranSmith, M., McDonald, M., \& Zeichner, K. (2005). Preparing teachers for a changing world: What teachers should learn and be able to do. San Francisco, CA: Jossey-Bass.

Johnson, A. G. (2006). Privilege, power, and difference ( $2^{\text {nd }}$ ed.). Boston, MA: McGraw-Hill. 
Jones, M. (2009). Transformational learners: Transformational teachers. Australian Journal of Teacher Education, 34(2), 14-27. Retrieved from http://ro.ecu.edu.au/cgi/ viewcontent.cgi?article $=1346 \&$ context $=$ ajte

King, K. P. (1997). Examining learning activities and transformational learning. International Journal of University Adult Education, 36(3), 23-37. Retrieved from Interaction Design Foundation: A Global Community of the World's Best Designers website: https://www.interactiondesign.org/refer ences/periodicals/international_journal_ of_university_adult_education.html

King, K. P. (2009). Handbook of the evolving research of transformative learning based on the learning activities survey (10th anniversary ed.). Charlotte, NC: Information Age Publishing.

Meyer, A., Rose, D., \& Gordon, D (2014). Universal design for learning: Theory and practice. Wakefield, MA: CAST.

Mezirow, J. (1991). Transformative dimensions in adult learning. San Francisco, CA: Jossey-Bass.

Mezirow, J., Taylor, E., \& Associates. (2009). Transformative learning in practice: Insights from community, workplace, and higher education. San Francisco, CA: Jossey-Bass.

National Center on UDL. (2013). How has UDL been defined? Retrieved from http://www.udlcenter.org
Quinnan, T. (1997). Adult students "atrisk": Culture bias in higher education. Westport, CT: Bergin and Garvey.

Roberts, D., Park, H. J., Brown, S., \& Cook, B. (2011). Universal design for instruction in postsecondary education: A systematic review of empirically based articles. Journal of Postsecondary Education and Disability, 24(1), 5-15. Retrieved from https://www.ahead.org/uploads/publicat ions/JPED/jped_24_1/JPED\%2024_1\%2 OFINAL\%20DOCUMENT.pdf

Smith, F. (2012). Analyzing a college course that adheres to the universal design for learning (UDL) framework. Journal of the Scholarship of Teaching and Learning, 12(3), 31-61. Retrieved from

http://files.eric.ed.gov/fulltext/EJ992116 .pdf

SoTL: What is the scholarship of teaching and learning (SoTL)? (2004).

Retrieved from University of Central Florida, Karen L. Smith Faculty Center for Teaching and Learning website: http://www.fctl.ucf.edu/

ResearchAndScholarship/SoTL/

Ukpokodu, O. (2003). Teaching multicultural education from a critical perspective: Challenges and dilemmas. Multicultural Perspectives, 5(4), 17-23. doi: $10.1207 / S 15327892 M C P 0504 \_4$ 
Vicki Caruana is an assistant professor of Education at Mount Saint Mary College in Newburgh, New York. She earned her PhD in Curriculum \& Instruction with an emphasis on Special Education Teacher Education from the University of South Florida. Vicki's research interests include transformative learning, curriculum development, strategy instruction and making learning accessible to students with learning disabilities.

Kelli Woodrow earned a PhD in Social Foundations, Policy, and Practice in Education from the University of Colorado at Boulder. All of her academic work and much of her employment has centered on education and equity. She has rural classroom teaching experience as a state-sponsored Migrant Education Teacher and Urban classroom experience as a bilingual elementary and middle school teacher. Kelli is currently an Associate Professor at Regis University in the School of Education.

Luis Pérez received his doctorate in special education from the University of South Florida. He is the author of Mobile Learning for All: Supporting Accessibility with the iPad, from Corwin Press. Luis is an Apple Distinguished Educator (ADE) and a Google Certified Teacher, and he currently serves as the Professional Learning Chair of the Inclusive Learning Network of the International Society for Technology in Education (ISTE). 